This work is licensed under a Creative Commons Attribution 4.0 International License.

Ovaj rad dostupan je za upotrebu pod međunarodnom licencom Creative Commons Attribution 4.0.

Nikolina Miletić, Marija Perić

\title{
IZRAŽAVANJE EMOCIJA FRAZEMIMA U DJEČJIM ZNANSTVENO-FANTASTIČNIM ROMANIMA
}

dr. sc. Nikolina Miletić, Sveučilište u Zadru,nmiletic2@unizd.hr, Zadar Marija Perić, Sveučilište u Zadru, mperic5@unizd.hr, Zadar

prethodno priopćenje

UDK 81'373.7

82.09-93-31

rukopis primljen: 27. kolovoza 2019; prihvaćen za tisak: 5. prosinca 2019.

Frazemi su sveze riječi čije značenje ne proizlazi iz značenja njihovih pojedinačnih komponenata te imaju sljedeće karakteristike: polileksikalnost, stabilnost i idiomatičnost (usp. Burger 2015: 11ff.). Mogu izražavati različite funkcije: (1) pokazatelji društvenih odnosa, (2) emocionalan stav govornika, (3) ironičnu ili humorističnu distancu, (4) eufemističko djelovanje, (5) argumentaciju i (6) klišeiziranost (usp. Fleischer 1997: 218ff.). Iz navedenih funkcija frazema ističe se njihova sposobnost evaluacije. Prema Du Boisu (2007: 139) je zauzimanje stava tj. evaluacija jedna od najvažnijih mogućnosti jezika. U okviru evaluacijske teorije Martin i White (2005) razlikuju stav, sudjelovanje i gradaciju. Stav se nadalje može podijeliti u afekt, sudi procjenu. $U$ ovome radu naglasak je stavljen na afekt tj. emocionalnu dimenziju značenja frazema. S obzirom da je jedna od karakteristika frazema njihova ekspresivnost promatrat će se izražavanje emocija kroz sam frazem te u kontekstu (usp. Burger 2015: 77). Cilj ovog rada je istražiti način izražavanja emocija frazemima u odabranim dječjim znanstveno-fantastičnim romanima. Uz to će se odgovoriti na sljedeća istraživačka pitanja: U kojoj se mjeri frazemi koriste za izražavanje emocija? Koje su emocije prisutne? Koja kategorija izražavanja emocija je najučestalija?

Ključne riječi: frazemi; znanstveno-fantastični romani; dječja literatura; teorija evaluacije; emocije 


\section{Teorijski pregled}

Naše emocije i način na koji o njima pričamo ključan su aspekt onoga što nas čini ljudima (usp. Bednarek 2008: 2). Svjesni smo emocija u sebi, neke možemo kontrolirati i sakriti, no neke nas mogu i savladati, te ih $\mathrm{u}$ nemogućnosti da ih sakrijemo možemo izraziti na različite načine te one tada mogu utjecati na naše postupke (usp. Fiehler 1990: 1). Riječi su nužne za identifikaciju emocija, a kako su one i sastavni dio svake kulture sa sobom nose određenu kulturno-specifičnu perspektivu te je istraživanje emocija jedna od ključnih sastavnica jezika (usp. Wierzbicka 1998: 25).

\subsection{Frazeologija i frazemi}

Frazemi su sveze riječi u kojima dolazi do gubitka značenja nekih ili svih sastavnica i čije značenje ne proizlazi iz značenja pojedinih sastavnica. Takve su sveze čvrste, što znači da ih govornik ne mijenja nego koristi kao gotovu cjelinu (usp. Menac 2006: 9). Frazemi također mogu biti i modificirani čime se mogu mijenjati semantički i formalno (za više vidi Burger 2015: 162-166). Fink-Arsovski (2002) dijeli frazeologiju na frazeologiju u užem i širem smislu. Svojstva frazema u širem smislu su ustaljenost, čvrsta struktura i cjelovitost. Svojstva frazema u užem smislu uključuju značenjsku preobliku, slikovitost, ekspresivnost i konotativno značenje.

Prema Burgeru (2015: 14f.) frazemi u širem smislu posjeduju obilježje polileksikalnosti i stabilnosti, dok frazemi u užem smislu imaju i obilježje idiomatičnosti. U frazeme u širem smislu svrstava kolokacije, komunikativne frazeme i poslovice, a $u$ frazeme $u$ užem smislu idiome. Prema Burgeru (2015: 32f.) idiom je idiomatična sveza riječi koja označava predmete i radnje. On može biti poluidiomatičan i idiomatičan. Ova je podjela u više navrata kritizirana, jer je nemoguće i nepoželjno frazeme tako striktno razvrstati.

Frazemi se mogu podijeliti prema funkcijama koje ispunjavaju $u$ komunikaciji na referentne, strukturalne i komunikativne. Referentni frazemi mogu imenovati i opisivati predmete i događaje. Strukturalni frazemi imaju funkciju uspostavljanja sintaktičkih odnosa. Komunikativni frazemi imaju funkciju uspostavljanja, definiranja, izvršavanja ili dovršavanja komunikativnih događaja (usp. Burger 2015: 31). Ova podjela je prihvaćena od velike većine znanstvenika kao primjerena i primjenjiva za istraživačke radove. 
Frazemi u tekstu mogu izražavati više funkcija. Funkcije frazema se određuju u određenom kontekstu, pri čemu jedan te isti frazem može ispunjavati istovremeno više funkcija. Prema Fleischeru (1997: 218ff.) frazemi izražavaju sljedeće pragmatične funkcije: (1) indikatori socijalnih odnosa u komunikativnoj situaciji, (2) emocionalni sastav (pozitivni ili negativni) prema određenoj situaciji ili osobi, (3) ironična ili posprdna distanca, (4) eufemistični učinak, (5) funkcija potkrijepljivanja argumenta i (6) funkcija klišea (korištenje slika za opisivanje kompleksnih situacija).

\subsection{Emocije kao dio evaluacije}

Na pitanje „Što su emocije?” ne postoji jednostavan odgovor. S jedne strane svako ljudsko biće zna što su emocije jer ih doživljava svakodnevno tijekom života te ih lako prepoznaje i kod drugih ljudi, no takvo znanje o emocijama ne može se lako pretočiti u jasne i korisne definicije (usp. Blount 1984: 130f.). Emocije „izražavaju odnos čovjeka prema svijetu koji ga okružuje” (Kovačević, Ramadanović 2016: 505f.). Ortner (2014: 13) navodi razne definicije emocija, pri čemu je svima zajedničko da su emocije iznenadne promjene: promjene s obzirom na tjelesne procese, na aktualnu situaciju, na povezanost s objektima i osobama, na spremnost djelovanja itd. Pri podjeli emocija veliku ulogu ima naša intuicija, naše životno iskustvo, naše znanje o svijetu, pojmovi u našem mentalnom leksikonu, kognitivne sheme itd. (usp. Ortner 2014: 21).

Fiehler (1990: 12-20) daje kratki pregled svih već istraživanih aspekata emocija: od onih koji istražuju komunikaciju emocija, oblike njihove manifestacije i izraza, mimiku, raspoznavanje emocija, nesvjesne tj. skrivene emocije, emotivnu tj. ekspresivnu funkciju jezika, emotivna jezična sredstva (vokabular, emotivno značenje i konotacije, uzvike, usklične rečenice, izraze, slikovitost i idiomatičnost) do onih koji se bave razlikama među spolovima, vrstama interakcije, svađama i konfliktima, komunikacijom liječnik-pacijent, jezičnim djelovanjem itd.

Evaluacija obuhvaća i prožima sve razine lingvističkog opisa: (1) fonološka razina (prozodijske karakteristike), (2) morfološka razina (evaluativni prefiksi ili sufiksi), (3) leksička razina (korištenje riječi ili izraza s evaluativnim teretom, (4) sintaktička razina (modalnost), (5) semantička razina (evaluativno značenje urođeno je nekim riječima i izrazima) (usp. Alba-Juez, Thompson 2014: 11). Ortner (2014: 189-197) u svom opisu emocija proširuje taj popis i daje pregled jezičnih sredstava za iskazivanje 
emocija, naslanjajući se na sljedeće autore: Fomina 1999, Fries 1994/1996/2003/2009, Jahr 2000, Janney 1996, Konstantinidou 1997, Kryk-Kastovsky, Löffelad 1990, Lüdke 2006ab, Schwarz-Friesel 2007, Volek 1987. (1) neverbalna razina (pogled, mimika), (2) fonetsko-fonološka razina (glas, intonacija, naglašavanje), (3) tipografska razina (grafički naglašeni elementi, zamjetna interpunkcija, veličina i tip slova, emotikoni), (4) morfološka/gramatička razina (deminutivi i augmentativi, emotivni afiksi i afiksoidi, komparativi i superlativi, anglizmi), (5) leksička razina (leksemi koji označuju emocije, emotivni, ekspresivni leksemi, stigmatizirane riječi, psovke, modalne čestice, ekspresivni neologizmi, onomatopejske riječi, frazemi, poslovice), (6) sintaktička razina (određene vrste izjavnih, imperativnih i upitnih rečenica, usklične rečenice, pasiv, red riječi, negacija), (7) pragmatička razina (pozdrav, psovke, ironija, sarkazam, zapovjedi, idiolekt, dijalekt, sociolekt), (8) stilistička razina (metafore, metonimije, usporedbe, hiperbole itd.) i (9) tekstualna razina (opisivanje emocija, tematiziranje paraverbalnih znakova i izraza itd.).

Emocije se prema Fiehleru (1990: 46f.) mogu promatrati kao evaluativno mišljenje „emocija A je evaluativno mišljenje o X na temelju Y kao Z", pri čemu X može biti situacija, radnja ili osobina druge osobe ili sebe, događaj, objekt itd., Y su očekivanja, interesi, želje, prihvaćene društvene norme, slika sebe ili drugih, a $Z$ znači da je nešto odgovarajuće ili neodgovarajuće. Prema Thompson i Hunston (2000: 6) osnovne funkcije evaluacije su (1) izraziti mišljenje govornika ili pisca i pritom reflektirati sistem vrijednosti te osobe i njihove zajednice, (2) sagraditi i održati odnose između govornika tj. pisca i slušatelja tj. čitatelja i (3) organizirati diskurs.

Ortner (2014: 239-248) u svojoj knjizi „Text und Emotion” u okviru emocija obrađuje i evaluaciju u okviru Martina i Whitea (2005), Bednarek (2006), Sandhöfer-Sixel (1990), Zillig (1982), Fries (1991) i dr. Kroz razgraničavanje samog pojma evaluacije Bednarek (2006) objašnjava cijeli niz povezanih pojmova, među kojima je i afekt, te navodi objašnjenje Thompson i Hunston (2000: 2) prema kojem se evaluacija bavi mišljenjima, dok se pojam afekt ponajprije koristi kada se razgovara o osjećajima i emocijama.

Evaluacijskom teorijom Martina i Whitea (2005) bave se razni autori (među ostalima u zborniku Thompson, Alba-Juez (2014) (Thompson, Macken-Horarik/Isaac, Alba-Juez/Attardo, Carretero/Taboada, Miller/ Johnson, Santamaria-Garcia), Thompson (2008), Križan (2016), Chen 
(2004), Coffin/O’Halloran (2006), Bednarek (2008). Prema Martinu i Whiteu (2005: 35-42) evaluacija se sastoji od tri interaktivne domene: stav, sudjelovanje i gradacija. Stav se bavi našim osjećajima, emocionalnim reakcijama, prosudama ponašanja i evaluacijom stvari te se nadalje dijeli u tri kategorije osjećaja: afekt, sud i procjenu. Afekt se bavi sredstvima stvaranja emocionalnih reakcija tj. registriranjem pozitivnih i negativnih osjećaja (npr. osjećamo li se sretno ili tužno, pouzdano ili anksiozno, zainteresirano ili kao da se dosađujemo), sud se bavi sredstvima procjenjivanja ponašanja prema raznim normativnim principima, a procjena se bavi sredstvima stvaranja vrijednosti stvari, uključujući i prirodne fenomene.

Fokus ovog rada je na poddomeni stava: afektu te će se taj pojam daljnje obrazložiti. U analizi afekta Martin i White (2005: 46-49) navode 6 faktora: (1) jesu li osjećaji od strane društva smatrani pozitivnima ili negativnima, (2) uključuju li osjećaji paralingvističku ili ekstralingvističku manifestaciju, (3) upućuju li osjećaji na nešto, reagiraju li na neki poseban emocionalni uzrok ili su samo generalno stanje pri čemu netko ne zna zašto se osjeća tako, (4) kako su osjećaji gradirani, (5) jesu li osjećaji realni ili irealni (npr. nekome se ne sviđa što mora otići - realno ili netko se boji odlaska - nerealno) te (6) tipologija afekta u tri skupine: (a) (ne)sreća emocije povezane sa srcem (tuga, sreća, mržnja, ljubav), (b) (ne)sigurnost emocije povezane s prirodno-društvenim blagostanjem (anksioznost, strah, samopouzdanje, povjerenje) i (c) (ne)zadovoljstvo - emocije povezane $s$ ispunjenjem nekih ciljeva (nezadovoljstvo, znatiželja, poštovanje).

Bednarek (2006: 41-58) na temelju evaluacijske teorije Martina i Whitea (2005) stvara vlastitu teoriju koja se sastoji od 9 parametara prema kojima govornici evaluiraju aspekte svijeta: osnovni evaluativni parametri su razumljivost, emocionalnost, očekivanost, važnost, mogućnost/nužnost i pouzdanost, dok su periferni evaluativni parametri evidencijalnost, mentalno stanje i stil ${ }^{1}$.

\section{Metodologija}

U sklopu bilateralnog projekta Upotreba frazema u konfliktnim dijalozima u književnosti za djecu i mlade (2018/2019) istražile smo upotrebu i ulogu

\footnotetext{
1 Core evaluative parameter: comprehensibility, emotivity, expectedness, importance, possibility/necessity, reliability and peripheral evaluative parameter: evidentiality, mental state, style.
} 
frazema u širem smislu u konfliktnim situacijama na korpusu dijaloga iz književnih djela za djecu i mlade te je iz tog korpusa proizašao ovaj rad.

Odabrani korpus čine dječji znanstveno-fantastični romani koji se nalaze na popisu lektire za 7. i 8. razred osnovne škole. Tekstovi za djecu do dobi od 12 godina se naziva dječjom književnošću. Značajke dječje književnosti su jednostavnost, pojednostavljivanje kompleksne unutarnje i vanjske stvarnosti koja se može izraziti s odgovarajućim pojednostavljenim jezičnim i književnim sredstvima. $\mathrm{Na}$ taj način se stvara napetost kao glavna estetska značajka dječje književnosti (usp. Eder 2010: 1577). Kriteriji odabira romana su domaći autor te novija godina izdanja (zadnjih 20 godina), što je rezultiralo četirima romanima: Zvonko Todorovski Prozor zelenog bljeska ${ }^{2}$ (2005), Zvonko Todorovski - Mirakul od mora ${ }^{3}$ (2007), Melita Rundek - Psima ulaz zabranjen ${ }^{4}$ (2000) te Snježana GrkovićJanović - Velebitske vilin-staze ${ }^{5}$ (2002).

Sva četiri romana su znanstveno-fantastični žanr. U Prozoru zelenog bljeska se u prozorskom staklu zaglavio anđeo Feliče, Korežina i Bartol postaju Dozivači koji pokušaju izbaviti Feličea iz stakla, serafin Klement zavladao je Trolistom, a Dozivači Korežina i Bartol, anđeo Feliče i Drevni Tomažo odluče namamiti informacijama Klementa u klopku. U Mirakulu od mora Andre dolazi na Hvar, u moru upoznaje boga mora Posejdona koji mu kaže da je on Glasnik jer mora upozoriti ljude da se u njihovoj uvali razmnožava opasna alga koja će uništiti sav biljni i životinjski svijet. U Psima ulaz zabranjen je Tomica predodređen da postane pisac, iako ne voli čitati lektire. Njegova najveća želja je imati psa i ta želja putuje gradom i traži odgovarajućeg psa. U toj potrazi joj pomaže kip koji je spomenik najvećem piscu u gradu. Tomica pronađe psa u knjižnici i od tada zavoli čitanje knjiga. U Velebitskim vilin-stazama glavni likovi Janko i Ranko upoznaju vile i patuljke koji žive na Velebitu. Zajedničkim snagama se bore za očuvanje prirodnih ljepota Velebita.

Čitajući romane ekscerpirale smo idiomatične frazeme u širem smislu te smo odabrale one koji izražavaju emocije. Potom smo te frazeme analizirale prema 5 sljedećih kategorija. Ponajprije smo frazeme podijelile $u$

\footnotetext{
2 U radu označena kraticom ZTPZB.

3 U radu označena kraticom ZTMOM.

4 U radu označena kraticom MRPUZ.

5 U radu označena kraticom SGJVVS.
} 
pozitivne i negativne te utvrdile izražava li se emocionalnost kroz sam frazem ili kontekst. Odredile smo postoji li emocionalna riječ u frazemu ili kontekstu. Naposljetku smo odredile koje su emocije najzastupljenije u primjerima te smo se pozabavile evaluacijskom teorijom Martina i Whitea (2005) i njihovom kategorijom afekta. Prema njihovom modelu emocije smo podijelile u 6 kategorije: sreća i nesreća, sigurnost i nesigurnost, zadovoljstvo i nezadovoljstvo.

U ovome radu smo odgovorile na sljedeća istraživačka pitanja: U kojoj se mjeri frazemi koriste za izražavanje emocija? Koje su emocije prisutne? Koja kategorija izražavanja emocija je najučestalija? Cilj ovog rada je pokazati način izražavanja emocija frazemima u odabranim dječjim znanstveno-fantastičnim romanima.

\section{Analiza}

Zbog prostornog ograničenja odabrana je nekolicina primjera za prikaz svih dijelova analize. Uvršteni su primjeri koji emocionalnost izražavaju kroz frazem i kontekst, koji sadrže emocionalnu riječ u frazemu i kontekstu te one koji je ne sadrže te su prikazani primjeri za svih 6 kategorija (sreća i nesreća, zadovoljstvo i nezadovoljstvo te sigurnost i nesigurnost).

U 4 dječja znanstveno-fantastična romana našeg korpusa nalazi se ukupno 79 emotivnih frazema. Od toga su 22 pozitivna i 57 negativna. Emocionalnost je 57 puta izražena kroz frazem, a 22 puta kroz kontekst.

(1) Nešto je zapucketalo dok se drugi dio sobe ozelenio snažnim mlazom svjetla, a trenutak poslije začuo se užasavajući krik probuđenog mačka! Zvučao je tim stravičnije što je bio potpuno nespojiv s Rufusovim temperamentom, koji jedva da je u svom mirnom mačjem životu ispustio i bijedno frktanje, a kamoli takav krik! Korežini su se skoro odsjekle noge od straha i vjerojatno bi pala da se rukom nije držala za prozorski okvir! Upravo kad je htjela vidjeti što se dogodilo Rufusu počelo se zbivati nešto čudno. Htjela je zakoračiti, ali nije se mogla pomaknuti s mjesta! Noge je nisu slušale! (ZTPZB 2005: 116)

U primjeru (1) nalazi se modifikacija odsjekle su se noge komu od straha koja dolazi od frazema otkazale su noge komu koji je emotivan sam po svome značenju 'ne može više hodati tko /od bolesti, od starosti, od umora i sl./' 
(Menac et al. 2014: 368). Korežina i Bartol željeli su spasiti Feličea, anđela koji je zapeo u staklu, tako da ga prebace u Korežininog mačka Rufusa. Eksperiment su proveli uspješno, Rufus je kriknuo, a Korežina se uplašila jer je mačak inače uvijek bio miran. U frazemu se nalazi emocionalna riječ strah te je po tome i sama emocija u primjeru strah koja pripada kategoriji nesigurnost.

(2) Pobjegao je, znači! - zaključi mirno Klement pa malo zastane.

- Pa dobro, s kim ja ovdje imam posla? - zaurla takvom silinom da su se Gospodstvima u trenu krila pretvorila u mokre krpe. Kao da se ništa nije dogodilo, progovori opet najljubaznijim, očaravajuće ugodnim glasom od kojega su Gospodstva odmah prešla na crveno usijanje. (ZTPZB 2005: 178)

U primjeru (2) nalazi se frazem imati posla koji po svome značenju '1. imati neugodnosti s kim, sčim; 2. biti u dodiru (vezi) s kim, s čim, kontaktirati $s$ kim' nije emocionalan (Menac et al. 2014: 442). Klement je ljut jer su mu pripadnici njegove anđeoske policije javili kako je Aldo - Dar Svjetla nestao, a oni su ga morali dovesti njemu. Emocionalnost se izražava kroz kontekst, tj. galeb Klement je ljutit i urla. U samom frazemu se ne nalazi emocionalna riječ, već je u kontekstu emocionalni glagol zaurlati što pridonosi negativnosti frazema Emocija koja je izražena je ljutnja te spada u kategoriju nesreća.

U korpusu se nalazi 46 primjera bez emocionalne riječi, 24 primjera u kojem se emocionalna riječ nalazi u kontekstu i 9 frazema s emocionalnom riječi.

(3) Makni nam se s puta, lugaru, i ne diži prašinu oko ovog posla. (SGJVVS 2002: 102)

U primjeru (3) nalazi se frazem s negacijom glagola dići/dizati prašinu <oko koga, oko čega> koji je po svome značenju 'izazvati/izazivati uznemirenost (skandal), činiti da se govori o kome, o čemu, uznemiriti/uznemirivati javnost čime' emotivan (Menac et al. 2014: 451). Drvosječe upozoravaju Janka da im se kloni s puta, jer oni imaju naredbu da posijeku sva stabla na tom području. U primjeru nema emotivne riječi, a emocija koju izražava je ljutnja i spada u kategoriju nesreća.

(4) Nisam te htio preplašiti, a zapravo i ne mislim tako crno. Još je mnogo nade ostalo i ljudima i patuljcima. (SGJVVS 2002: 99) 
U primjeru (4) nalazi se modifikacija frazema s negacijom glagola misliti crno koja dolazi od frazema gledati crno sa značenjem 'biti pesimist, pesimistično promatrati stvari, uočavati samo loše strane čega' koje je emotivno (Menac et al. 2014: 62). Emocionalne riječi preplašiti i nada nalaze se $\mathrm{u}$ kontekstu. U primjeru se izražava emocija nada te spada u kategoriju nesreća. Hrastolist (patuljak) govori Ranku (Kankovom nećaku) kako nošenje puške nikome dobroga nije donijelo, ali u svemu tome on ostaje pozitivan i gaji nadu u dobro u ljudima.

(5) I Hrastolist nešto povjeri svojoj bradi, a to je čuo samo Ranko jer je stajao do njega: Tko se posljednji smije, najslađe se smije. (SGJVVS 2002: 99)

U primjeru (5) nalazi se poslovica tko se posljednji smije, najslađe se smije sa značenjem 'raduje se, veseli se onaj za kojeg se pokaže da je imao pravo' (HJP). Samo značenje je emocionalno, a u poslovici se također nalazi i emocionalni glagol smijati se. Poslovicom je izraženo zadovoljstvo koje pripada kategoriji zadovoljstvo. Janko (lugar) i Hrastolist (patuljak) se prepiru oko nošenja oružja. Janko nosi pušku kako bih otjerao drvosječe, ali ju ne misli upotrijebiti nego služi samo kao sredstvo za utjerivanje straha. Hrastolist je optimističan i želi da svi ljudi ovog svijeta prestanu koristiti oružje.

Frazemi su podijeljeni u šest kategorija, pri čemu neki primjeri mogu biti svrstani istovremeno u više kategorija, npr. frazem u kontekstu može izražavati kako je netko istovremeno sretan i zadovoljan zbog nečega. 13 frazema nalazi se u kategoriji sreća, 27 u kategoriji nesreća, 10 u kategoriji zadovoljstvo, 5 u nezadovoljstvo, $1 \mathrm{u}$ sigurnost te $25 \mathrm{u}$ nesigurnost.

(6) Činilo se da su se odmah sprijateljili. Nešto poput ljubavi na prvi pogled. (MRPUZ 2000: 18)

U primjeru (6) nalazi se frazem ljubav na prvi pogled sa značenjem 'ljubav koja bukne pri prvom susretu' (Menac et al. 2014: 303). Gospođa knjižničarka se sprijateljila sa psom čim ga je ugledala i počeškala ispod brade, dok se direktor popeo na stolicu od straha. Frazem sam po sebi izražava emocionalnost i u sebi sadrži emocionalnu riječ ljubav. Frazemom se izražava emocija ljubav koja pripada kategoriji sreća.

(7) Oprosti, Tomažo, pa znaš da nisam htio... - Oprosti, oprosti! - žestio se Tomažo, ali sada samo reda radi. - Jedino pametno što od tebe čujem jest oprosti! Kad ostaneš bez glave, kako ćeš vikati "oprosti"? Razmišljaj malo. (ZTPZB 2005: 199) 
U primjeru (7) nalazi se modifikacija ostati bez glave koja dolazi od negativnog frazema izgubiti glavu (život) sa značenjem 'poginuti' (Menac et al. 2014: 139). Tomaž je ljut na Bartola jer ga nije poslušao. Bartol se trebao okupati u čarobnom jezeru koje će ga ozdraviti, a pritom mu je Tomaž zabranio da u njemu roni, što Bartol nije poslušao i time je došao u opasnost. Frazem izražava emocionalnost, a emocionalni glagol žestiti se nalazi se u kontekstu. Frazemom je izražena emocija ljutnja koja pripada kategoriji nesreća.

(8) Ranko jedva dočeka da se sretne u osami sa starim prijateljem, a na otoku bijaše u izobilju prelijepih, samotnih mjesta gdje se o tajnama moglo slobodno govoriti. Uz pjesnika, Ranko rastereti dušu. (SGJVVS 2002: 152)

U primjeru (8) nalazi se modifikacija rasteretiti dušu koja dolazi od pozitivnog frazema olakšati dušu sa značenjem 'ispovjediti se komu, izjadati se komu' (Menac et al. 2014: 111). Emocionalnost je izražena kroz sam frazem, a u kontekstu nema emocionalne riječi. Frazem izražava emociju olakšanje koja pripada kategoriji sigurnost. Ranko (Jankov nećak) nakon Jankove smrti po prvi puta razgovara otvoreno o životu na Velebitu, o vilama i patuljcima. Cijeli život je to držao samo za sebe, a sada se može povjeriti pjesniku, Jankovom prijatelju.

(9) Ne sjećam se kako smo se vratili. Magda je pokušala razgovarati, no nisam mogao guknuti ni slovo. (ZTMOM 2007: 36)

U primjeru (9) nalazi se negativan frazem ne moći guknuti ni slovo koji je modifikacija frazema ne izreći ni slovo. Andre i Magda bili su s Magdinim prijateljima s Hvara na kupanju te su se oni Andri rugali jer je iz Zagreba. Andri se to ne sviđa, a Magda opravdava svoje prijatelje i njihove šale. Andre se osjeća nesigurno i želi ići kući i biti sam u svojoj sobi. Emocionalnost je izražena kroz kontekst, a u kontekstu se ne nalazi emocionalna riječ. Emocija u primjeru je nesigurnost koja pripada kategoriji nesigurnost.

(10) Priznajem da ovo nije zvučalo blesavo. Nisam se uplašio, nisam osjetio strah i odmah sam znao tko je. I što je najvažnije, nisam napravio budalu od sebe pričajući uokolo o njemu. (ZTMOM 2007: 61)

U primjeru (10) nalazi se frazem s negacijom uz glagol napraviti/ praviti budalu od koga sa značenjem 'narugati se/rugati se komu, ismijati/ 
ismijavati koga, učiniti/činiti koga smiješnim' (Menac et al. 2014: 54). Andre je s prijateljima imao natjecanje u ronjenju te je pritom upoznao boga mora Posejdona i ronio je 4 minute jer je bio s njime. Andre je odabran da bude Glasnik jer se u moru razmnožava opasna alga i treba upozoriti ljude te je Andre ponosan što je uspješno razgovarao s Posejdonom bez da se osramotio. Emocionalnost je izražena samim frazemom, a negacije emocionalnih riječi uplašiti i strah se nalaze u kontekstu. Izražena je emocija zadovoljstvo u kategoriji zadovoljstvo.

(11) Vi Drevni nekada ste bili ratnici? - Kakvih Trolist nije vidio! - uskliknuo je Tomažo. - Ali pamet sporo putuje. Kroz beskrajni niz stoljeća ona je iz repa jedva stigla do glave. Nikada nas nije bilo mnogo, pa smo se u međuplemenskim ratovima gotovo istrijebili. To je povijest naše gluposti! Zato sada vladaju žene. Moram priznati da su mudrije od nas, i drugačije rješavaju probleme. (ZTPZB 2005: 208)

U primjeru (11) nalazi se modifikacija iz repa stići do glave koja dolazi od frazema došlo je iz guzice (dupeta) u glavu komu što sa značenjem 'konačno je shvatio tko što, dugo je trebalo komu, ali napokon je shvatio tko što' (Menac et al. 2014: 170). Tomažo priča Bartolu priču o svome svijetu te kaže kako si oni, Drevni, nekoć bili ratnici no da su se međusobno borili i zbog toga ih je malo. Tek kasnije su se opametili, pa sada vlada žena. Negativna emocionalnost je izražena kroz kontekst, a u kontekstu nema emocionalnih riječi. Emocija u primjeru je nezadovoljstvo koja spada u kategoriju nezadovoljstvo.

\section{Zaključak}

U europskom kulturnom krugu rašireno je mišljenje kako su naši pravi, iskreni osjećaji nešto osobno, intimno što ne dijelimo sa svim ljudima, posebno ukoliko emocije poput straha ili bijesa utječu na naše ponašanje koje može promijeniti i ugroziti sliku o nama ili drugim ljudima otkriti naše slabosti (usp. Ortner 2014: 1). Književnost djeluje kao most za lakše shvaćanje i jezično izražavanje emocija. Ortner (2014: 306) navodi kako ona ima važnu ulogu u kulturnom razumijevanju emocija, jer su za književnost tipične igre sa stvarnošću, za autentičnosti i fikcijom, normama tekstualne vrste kao i društvenim normama, eksperimenti s kreativnom slobodom, estetskom tradicijom i inovacijom kao i konvencijama s obzirom na prikaz emocija (usp. Hogan 2003: 2, Kruse 2002: 108). 
Kao jedno od jezičnih sredstava koja se često spominju u vidu ekspresivnosti i emocionalnosti su frazemi. Takav način izražavanja emocija tematizira se u ovom radu. Na korpusu od 4 dječja znanstveno-fantastična romana istraženi su frazemi koji izražavaju emocije te su analizirani prema sljedećim kategorijama:

(1) Frazemi su podijeljeni na pozitivne i negativne te se $u$ našem korpusu od ukupno 79 emotivnih frazema nalaze 57 negativna i 22 pozitivna frazema. Takvi rezultati nisu iznenađujući, jer u pisanom korpusu prevladavaju negativna jezična sredstva (usp. Havryliv 2009: 17).

(2) Frazemi mogu izražavati emocije samim svojim značenjem ili u kontekstu. U našem radu emocionalnost je većinski izražena kroz frazem, čak 57 puta, a 22 puta kroz kontekst. Zbog uske povezanosti ekspresivnosti (kao jedne od karakteristika frazema (usp. Burger 2015: 81)) i emocionalnosti u korpusu prevladava izražavanje emocija kroz frazem.

(3) Kao treći aspekt analize istražena je postojanost emocionalne riječi, tj. ukoliko postoji, nalazi li se ona u frazemu ili kontekstu. Rezultati istraživanja pokazuju kako je najviše primjera, čak 46, bez emocionalne riječi, 24 primjera sadrži emocionalnu riječ u kontekstu, a samo 9 primjera sadrži emocionalnu riječ u samom frazemu. Iz toga se da zaključiti kako za emocionalnost frazema nije nužno postojanje emocionalne riječi u frazemu ili kontekstu.

(4) U primjerima je utvrđeno koja se emocija izražava. Najčešće emocije su nesigurnost (13 primjera) i ljutnja (11 primjera). Nakon toga se izražavaju sreća, nesreća, ljubav, tuga, zadovoljstvo i strah (6 puta), nezadovoljstvo i zabrinutost (4 puta), te ostale emocije (potresenost, nada, ponos, očaj, olakšanje, sigurnost, šok).

(5) Prema evaluacijskoj teoriji Martina i Whitea (2005) i njihovoj kategoriji afekta emocije su podijeljene u kategorije sreća i nesreća, sigurnost i nesigurnost te zadovoljstvo i nezadovoljstvo. Prema našem istraživanju najviše se frazema nalazi u kategorijama nesreća (27 frazema s emocijama ljutnja, nesreća i tuga) te nesigurnost (25 frazema s emocijama nesigurnost, strah i zabrinutost). Potom su zastupljene kategorije sreća (13 frazema s emocijama sreća i ljubav), zadovoljstvo (10 frazema s emocijama ponos i zadovoljstvo), nezadovoljstvo (5 frazema s emocijom nezadovoljstvo) te sigurnost (2 frazema s emocijom sigurnost). U analizi je utvrđeno kako poneki primjeri ne izražavaju samo jednu emociju, zbog čega su svrstani u dvije različite kategorije, npr. netko može biti nesretan i nezadovoljan u isto vrijeme. 


\section{Literatura}

Alba-Juez, Laura; Attardo, Salvatore (2014) „The evaluative palette of verbal irony", Evaluation in Context, ur. Geoff Thompson i Laura AlbaJuez, Amsterdam - Philadelphia, 93-116.

Bednarek, Monika (2006) Evaluation in Media Discourse. Analysis of a Newspaper Corpus, Continuum, New York - London.

Bednarek, Monika (2008) Emotion Talk Across Corpora, Palgrave Macmillan, Hampshire - New York.

Blount, Ben G. (1984) „The Language of Emotions. An Ontogenetic Perspective", Language Sciences, 6, 1, 129-156.

Burger, Harald (2015) Phraseologie. Eine Einführung am Beispiel des Deutschen, Erich Schmidt Verlag, Berlin.

Carretero, Marta; Taboada, Maite (2014) „Graduation within the scope of Attitude in English and Spanish consumer reviews of books and movies", Evaluation in Context, ur. Geoff Thompson i Laura AlbaJuez, Amsterdam - Philadelphia, 221-240.

Chen, Lily (2004) „Evaluation in Media Texts: A Cross-Cultural Linguistic Investigation", Language in Society 33, 673-702.

Coffin, Caroline; O'Halloran, Kieran (2006) „The role of appraisal and corpora in detecting covert evaluation", Functions of Language 13, 1, 77-110.

Eder, Ulrike (2010) „Kinder- und Jugendliteratur im Deutsch als Fremdund Zweitspracheunterricht", Deutsch als Fremd- und Zweitsprache. Ein internationales Handbuch, ur. Hans-Jürgen Krumm, Christian Fandrych, Britta Hufeisen, Claudia Riemer, Berlin, 1577-1583.

Fiehler, Reinhard (1990) Kommunikation und Emotion: theoretische und empirische Untersuchungen zur Rolle von Emotionen in der verbalen Interaktion, de Gruyter, Berlin - New York.

Fink-Arsovski, Željka (2002) Poredbena frazeologija: pogled izvana i iznutra, FF Press, Zagreb.

Fleischer, Wolfgang (1997) Phraseologie der deutschen Gegenwartssprache, Niemeyer, Tübingen.

Fomina, Sinaida (1999) „Grundtypen der emotional wertenden Lexik im emotiven Vokabular der deutschen Gegenwartssprache”, Zeitenwende - die Germanistik auf dem Weg vom 20. ins 21. Jahrhundert, ur. Peter Wiesinger, Bern, 393-399. 
Fries, Norbert (1991) „Bewertung. Linguistische und konzeptuelle Aspekte des Phänomens", Sprache und Pragmatik 23, 1-31.

Fries, Norbert (1994) „Grammatik, Emotionen und Äußerungsbedeutung.”, Sprache und Pragmatik 33, 1-37.

Fries, Norbert (1996) „Grammatik und Emotionen”, Sprache und Pragmatik 38, 1-39.

Fries, Norbert (2003) „de ira: particulae collectae. Festschrift für Harald Weydt zum 65. Geburtstag", Linguistik online 2003/13 (1).

Fries, Norbert (2009) „Die Kodierung von Emotionen in Texten. Teil 2: Die Spezifizierung emotionaler Bedeutung in Texten", Journal of Literary Theory 3 (1), 19-71.

Thompson, Geoff (2008) „Appraising glances: evaluating Martin's model of APPRAISAL", <i>WORD</i>, 59, 1-2, 169-187.

Grković-Janović, Snježana (2002) Velebitske vilin staze, Naklada Bošković, Split.

Jahr, Silke (2000). Emotionen und Emotionsstrukturen in Sachtexten, Walter de Gruyter, Berlin.

Janney, Richard W. (1996). Speech and affect. Emotive uses of English, o.V, München.

Konstantinidou, Magdalene (1997) Sprache und Gefühl. Semiotische und andere Aspekte einer Relation, Buske, Hamburg.

Kovačević, Barbara; Ramadanović, Ermina (2016) „Primarne emocije u hrvatskoj frazeologiji”, Rasprave 42, 2, 505-527.

Križan, Agata (2016) „The social aspect of the discourse-semantic appraisal model in British advertisements: The category of attitude.", Jezikoslovlje 17, 3, 643-665.

Kryk-Kastovsky, Barbara (1997) „Suprise, suprise. The iconicity-conventionality scale of emotions". The language of emotions. Conceptualization, expression, and theoretical foundation, ur. Susanne Niemeyer i Rene Dirven, Amsterdam, Philadelphia, 155-169.

Löffelad, Peter (1990) „Emotionale Modalisatoren in südwestdeutscher Alltagssprache", Sprache: Emotion, ur. Karl Sornig i Norman Denison, Graz, 165-182.

Lüdke, Ulrike M. (2006a) „Emotion und Sprache: Neurowissenschaftliche und linguistische Relationen”, Die Sprachheilarbeit 51, 4, 160-175. 
Lüdke, Ulrike M. (2006b) „Sprache und Emotion: Neurowissenschaftliche und linguistische Zusammenhänge", Sprache - Emotion - Bewusstheit. Beiträge zur Sprachtherapie in Schule, Praxis, Klinik, ur. Reiner Bahr i Claudia Iven, Idstein, 17-26.

Macken-Horarik, Mary; Isaac, Anne (2014) „Appraising Appraisal”, Evaluation in Context, ur. Geoff Thompson i Laura Alba-Juez,. Amsterdam Philadelphia, 67-92.

Martin, J. R., White, P. R. R. (2005) The Language of Evaluation. Appraisal in English, Palgrave Macmillan, London.

Menac, A.; Fink-Arsovski, Ž.; Venturin, R. (2014) Hrvatski frazeološki rječnik, Naklada Ljevak, Zagreb.

Menac, Antica (2007) Hrvatska frazeologija, Školska knjiga, Zagreb.

Miller, Donna R.; Johnson, Jane H. (2014) „Evaluative phraseological choice and speaker party/gender: A corpus-assisted comparative study of 'register-idiosyncratic' meaning in Congressional debate", Evaluation in Context, ur. Geoff Thompson i Laura Alba-Juez, Amsterdam - Philadelphia, 345-366.

Ortner, Heike (2014) Text und Emotion. Theorie, Methode und Anwendungsbeispiele emotionslinguistischer Textanalyse, Narr Verlag, Tübingen.

Rundek, Melita (2000) Psima ulaz zabranjen, Školska knjiga, Zagreb.

Sandhöfer-Sixel, Judith (1990) „Emotionale Bewertung als modale Kategorie", Sprache: Emotion, ur. Karl Sornig, Norman Denison, Graz, 267-278.

Santamaria-Garcia, Carmen (2014) „Evaluative discourse and politeness in university students' communication through social networking sites", Evaluation in Context, ur. Geoff Thompson i Laura Alba-Juez, Amsterdam - Philadelphia, 387-412.

Schwarz-Friesel, Monika (2007) Sprache und Emotion, Francke. Tübingen, Basel.

Thompson, Geoff (2014) "Affect and emotion, target-value mismatches, and Russian dolls: refining the appraisal model", Evaluation in Context, ur. Geoff Thompson i Laura Alba-Juez, Amsterdam Philadelphia, 47-66.

Thompson, Geoff; Alba-Juez, Laura. (2014) Evaluation in Context, John Benjamins, Amsterdam - Philadelphia. 
Thompson, Geoff; Hunston, Susan (2000) "Evaluation: An Introduction", Evaluation in Text, ur. Geoff Thompson, Susan Hunston, New York, $1-27$.

Todorovski, Zvonko (2005) Prozor zelenog bljeska, Naklada Lukom, Zagreb.

Todorovski, Zvonko (2007) Mirakul od mora, Alfa, Zagreb.

Volek, Bronislava (1987) Emotive signs in language and semantic functioning of derived nouns in Russian, Benjamins (=Linguistic and literary studies in Eastern Europe [LSEE] 24), Amsterdam, Philadelphia.

Wierzbicka, Anna (1998) „Sadness" and "anger" in Russian: The nonuniversality of the so-called "basic human emotions"', Speaking of emotions, ur. Angeliki Athanasiadou i Elzbieta Tabakowska, Berlin New York, 3-28.

Zillig, Werner (1982) Bewerten. Sprechakttypen der bewertenden Rede, Niemeyer, Tübingen.

\section{SUMMARY}

Nikolina Miletić, Marija Perić

\section{PHRASEMES EXPRESSING EMOTIONS IN CHILDREN'S SF NOVELS}

Phrasemes are combinations of words whose meaning does not derive from the meaning of their individual components. They have the following characteristics: polylexicality, stability and idiomaticity (cf. Burger 2015: 11ff.). They may express different functions: (1) indicators of social relations, (2) emotional attitude of the speaker, (3) ironic or humorous distance, (4) euphemistic action, (5) argumentation, and (6) clichés (cf. Fleischer 1997: 218ff.). The aforementioned functions of the phrasemes highlight their ability to evaluate. According to Du Bois (2007: 139), taking a stance, i.e. evaluation, is one of the most important language characteristics. Within the evaluation theory, Martin and White (2005) distinguish attitude, engagement and gradation. Attitude can further be divided into affect, judgment and appreciation. In this paper, the emphasis is placed on affect, i.e. the emotional meaning of phrasemes. The aim of this paper is to show the way emotions are expressed by phrasemes in selected children's SF novels. In addition, the following research questions will be answered: Are phrasemes used to express emotions? Which emotions are present? Which category of expressing emotions is the most common?

Key words: phrasemes; SF novels; children's literature; evaluation theory; emotions 